\title{
Complexation and Extraction of PAHs to the Aqueous Phase with a Dinuclear Pt ${ }^{\text {II }}$ Diazapyrenium-Based Metallacycle**
}

\author{
Víctor Blanco, ${ }^{[a]}$ Marcos D. García, ${ }^{[a]}$ Alessio Terenzi, ${ }^{[b]}$ Elena Pía, ${ }^{[a]}$ \\ Antonio Fernández-Mato, ${ }^{[a]}$ Carlos Peinador, ${ }^{*[a]}$ and José M. Quintela*[a]
}

Dedicated to Professor José Barluenga on the occasion of his 70th birthday

\begin{abstract}
New palladium and platinum metallacycles have been synthesized by reaction between a 2,7-diazapyreniumbased ligand and $\mathrm{Pd}^{\mathrm{II}}$ and $\mathrm{Pt}^{\mathrm{II}}$ complexes. The inclusion complexes between the metallacycles and polycyclic aromatic hydrocarbons (PAHs) in $\mathrm{CD}_{3} \mathrm{NO}_{2}$ and $\mathrm{D}_{2} \mathrm{O}$ were studied by NMR spectroscopy. The structures of the inclusion complexes of the Pt metallacycle as host with pyrene, phenanthrene, and triphenylene were con-
\end{abstract}

firmed by single crystal X-ray crystallography. The association constants between the Pt metallacycle and the selected PAHs were determined in $\mathrm{CH}_{3} \mathrm{CN}$ following the characteristic charge-transfer band displayed in their

Keywords: inclusion compounds • metallacycles $\cdot$ polycyclic aromatic hydrocarbons • self-assembly supramolecular chemistry
UV/Vis absorption spectrum. Although in aqueous solution all the complexes showed a 1:1 stoichiometry, in $\mathrm{CH}_{3} \mathrm{CN}$ the Job plot indicated a 2:1 stoichiometry for complexes with triphenylene and benzo $[a]$ pyrene. The estimated association constants in water correlate with the hydrophobicity of the PAH, indicating that hydrophobic forces play an important role in the complexation process.

\section{Introduction}

Polycyclic aromatic hydrocarbons (PAHs) represent an important group of environmental pollutants characterized by two or more fused aromatic rings. ${ }^{[1]}$ PAHs are introduced into the environment from various sources, such as natural oil seeps, refinery and oil storage wastes, accidental spills from oil tankers, petrochemical industrial effluents, coal tar processing wastes, combustion processes, and wood preservative wastes. ${ }^{[2]}$ Their omnipresent distribution, environmen-

[a] Dr. V. Blanco, Dr. M. D. García, E. Pía, Dr. A. Fernández-Mato, Prof. C. Peinador, Prof. J. M. Quintela

Departamento de Química Fundamental, Universidade da Coruña Facultad de Ciencias, A Zapateira, s/n, 15008 La Coruña (Spain) Fax: (+34) 981-167065

E-mail: carlos.peinador@udc.es jqqoqf@udc.es

[b] A. Terenz

Dipartimento di Chimica Inorganica e Analitica "S. Cannizzaro" Università di Palermo, Viale delle Scienze Parco d'Orleans II, Edificio 17, 90128 Palermo (Italy)

[**] $\mathrm{PAH}=$ polycyclic aromatic hydrocarbon.

Supporting information for this article is available on the WWW under http://dx.doi.org/10.1002/chem.201002051. tal persistence, and potentially deleterious effect on human health have resulted in an increasing interest by the research community. ${ }^{[3]}$ PAHs are characterized by their hydrophobicity and tendency to accumulate in the organic matter. Appropriate extraction techniques should enhance the solubility of the compounds, to extract their entire labile fraction. Cyclodextrin and resin extractions have shown their potential as suitable approaches for addressing the problem. ${ }^{[4]}$

Metal-directed self-assembly has been one of the most exploited areas in supramolecular chemistry in recent years. ${ }^{[5]}$ The development of this supramolecular strategy has allowed the preparation of topologically unusual supramolecules, such as catenanes, rotaxanes, and knots. ${ }^{[6]}$ Likewise, metal-coordination-directed self-assembly has also led to the preparation of molecular triangles, squares, pentagons, and hexagons, which can be regarded as potential hosts because of their cavities. ${ }^{[7]}$ Although, the number of those molecular receptors capable of complexing medium-size substrates remains low. ${ }^{[8]}$ The combination of pyridyl ligands with palladium or platinum centers has become a powerful and versatile tool to synthesize $2 \mathrm{D}$ and $3 \mathrm{D}$ suprastructures. ${ }^{[9]}$ The success of this approach is based on the structural diversity of pyridyl ligands, the geometry of the metal center, and the modulation of the lability of the coordination bond. 
In a recent communication, we reported the complexation of pyrene in aqueous solution with a self-assembled rectangular palladium metallacycle. ${ }^{[10]}$ The molecular recognition process is based on hydrophobic forces and $\pi$-donor/ $\pi$-acceptor interactions between pyrene and the electronic $\pi$-deficient 4,4'-bipyridinium moieties of the metallacycle. It is well known that 2,7-diazapyrene is a better electron acceptor than 4,4'-bipyridine increasing the hydrophobic nature of the resulting metallacycle due to the extended aromatic surface and increasing in that manner the potential of the receptor to complex $\pi$-extended aromatic species on an aqueous environment. With the aim of completing and expanding the former study, in this paper we report a new diazapyrenium-based metallacyclic receptor and its inclusion complexes with pyrene and other PAHs. This water-soluble host has a suitable size to form inclusion complexes with a wide range of PAHs. Moreover, the potential of this host to selectively complex targeted aromatic substrates is also outlined by the use of competitive extraction experiments of several PAHs to an aqueous phase.

\section{Results and Discussion}

The aromatic nucleophilic substitution of 4-chloro-1,3-dinitrobenzene with 2,7-diazapyrene produced the activated intermediate $N$-(2,4-dinitrophenyl)-2,7-diazapyrenium salt (1; Scheme 1). For the preparation of ligand $\mathbf{3} \cdot \mathrm{NO}_{3}$ we used the Zincke reaction. ${ }^{[1]}$ The exchange of the 2,4-dinitroaniline moiety by 4-(pyridin-4-ylmethyl)aniline (2) gave, presumably by an addition of the nucleophile, ring opening and ring closing (ANRORC) mechanism, the ligand $3 \cdot \mathrm{PF}_{6}$. The nitrate salt was prepared by metathesis of $3 \cdot \mathrm{PF}_{6}$ with tetrabutylammonium nitrate (TBAN). To the best of our knowledge, this is the first example of the Zincke reaction with a 2,7-diazapyrene derivative. The proposed structure of ligand $3 \cdot \mathrm{PF}_{6}$ was confirmed by means of X-ray crystallography of suitable single crystals obtained by vapor diffusion of ethyl ether into a $\mathrm{CH}_{3} \mathrm{CN}$ solution of a monoprotonated form of the ligand (see the Supporting Information). Thus, the structure showed the pyridine ring protonated at the nitrogen atom and, consequently, the presence of two hexafluorophosphate counteranions. The dihedral angle between the planes defined by the phenylene and diazapyrene systems is $52^{\circ}$.

Synthesis of $\mathrm{Pd}^{\mathrm{II}}$ and $\mathrm{Pt}^{\mathrm{II}}$ metallacycles $5 \mathrm{a}$ and $5 \mathrm{~b}$ : According to the usual methodology employed in our investigations, ${ }^{[12]}$ we checked if metallacycle $\mathbf{5}$ a could be self-assembled from ligand $3 \cdot \mathrm{NO}_{3}$ and the palladium complex $4 \mathbf{a}$. The ${ }^{1} \mathrm{H}$ and ${ }^{13} \mathrm{C}$ NMR spectra of an equimolar solution of $\mathbf{3} \cdot \mathrm{NO}_{3}$ (5.0 mM) and $4 \mathbf{a}$ in $\mathrm{D}_{2} \mathrm{O}$ showed chemical shifts compatible with the metallacycle formation. The downfield shift of protons $\mathrm{H}_{\mathrm{a}}$ and $\mathrm{H}_{\mathrm{h}}$ and the upfield shift of $\mathrm{H}_{\mathrm{b}-\mathrm{e}}$ clearly suggested the complexation of ligand $\mathbf{3}$ to the metal center and the formation of the rectangle (Figure 1). The presence of other cyclic structures was discarded by dilution experiments monitored by ${ }^{1} \mathrm{H}$ NMR spectroscopy, since the spectra exhibited no changes over the $2.5-0.5 \mathrm{~mm}$ range. The diffusion coefficients obtained from DOSY (diffusion-ordered NMR spectroscopy) experiments of metallacycle $\mathbf{5 a} \cdot 6 \mathrm{NO}_{3}$ showed that the metallacycle is larger than its components as the diffusion coefficient is lower than the values obtained for the free components in separate experiments. Moreover, the signals from the ligand and palladium complex displayed the same diffusion coefficients, implying both components diffusing as a whole.

The self-assembly also proceeded in $\mathrm{CH}_{3} \mathrm{NO}_{2}$ solution with similar results. However, the ${ }^{1} \mathrm{H}$ NMR spectrum of $\mathbf{5 a} \cdot 6 \mathrm{PF}_{6}$ in $\left[\mathrm{D}_{3}\right]$ nitromethane revealed the existence of other<smiles>O=[N+]([O-])c1ccc(-[n+]2cc3ccc4cncc5ccc(c2)c3c45)c([N+](=O)[O-])c1</smiles>
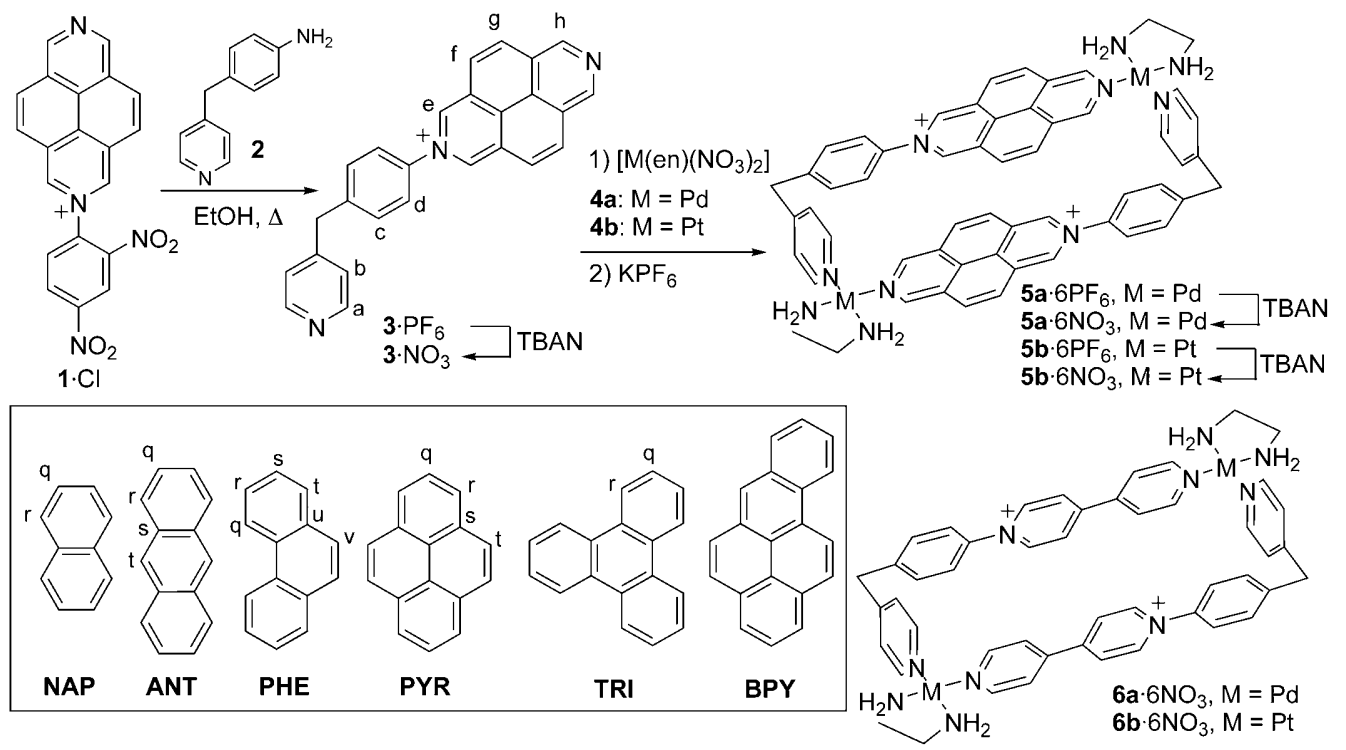

Scheme 1. Synthesis of metallacycles $\mathbf{5} \mathbf{a}$ and $\mathbf{5 b}$ and selected PAHs used in this work. en =ethylenediamine. 


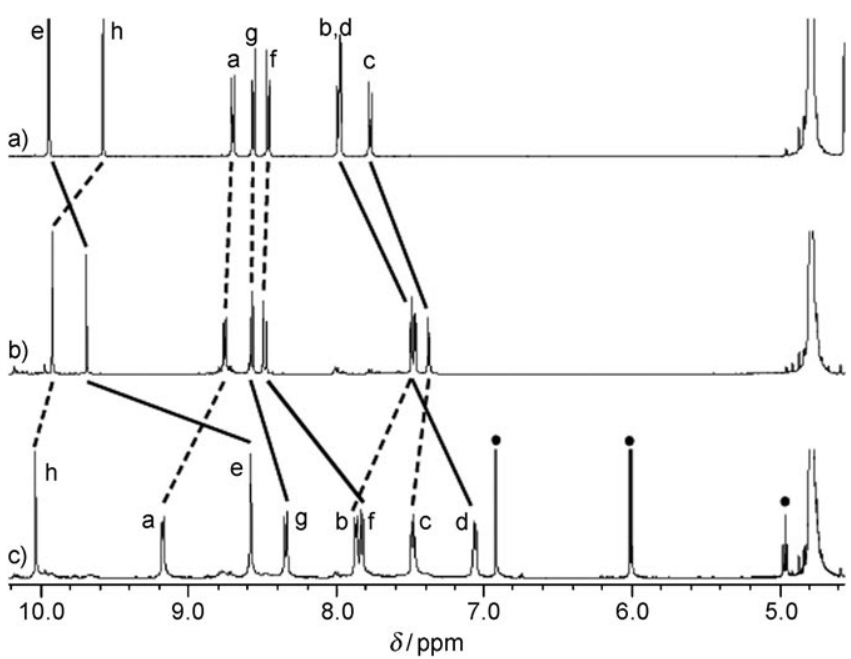

Figure 1. Partial ${ }^{1} \mathrm{H}$ NMR $\left(\mathrm{D}_{2} \mathrm{O}, 500 \mathrm{MHz}\right)$ spectra of a) ligand $\mathbf{3} \cdot \mathrm{NO}_{3}$, b) metallacycle $\mathbf{5} \cdot \mathbf{a} \cdot 6 \mathrm{NO}_{3}$, and c) inclusion complex $\mathrm{PYR} \subset \mathbf{5} \mathbf{a} \cdot 6 \mathrm{NO}_{3}$. Pyrene signals are marked as black dots.

minor species when the concentration is $1 \mathrm{~mm}$ or higher, while at concentrations below $0.5 \mathrm{~mm}$ only the dinuclear metallacycle was detected.

As described above, the self-assembly of palladium metallacycles $\mathbf{5}$ a proceeded instantaneously at room temperature. Nevertheless, the known lability of the $\mathrm{Pd}-\mathrm{N}(\mathrm{Py})$ bond makes their isolation and an accurate structural characterization difficult. The use of the more inert $\mathrm{Pt}-\mathrm{N}$ bond should allow us to surpass those inconveniences. The $\mathrm{Pt}-\mathrm{N}$ coordination bond has double characteristics owing to its inertness at low temperature, which is lost when the temperature is increased. This dual feature has been exploited by Fujita to introduce the "molecular lock" concept. ${ }^{[13]}$ Employing this strategy we could prepare the platinum analogues of metallacycles $5 \mathbf{b}$. Obviously, the reaction time (8 d) and temperature $\left(100^{\circ} \mathrm{C}\right)$ were higher to assure the thermodynamic control over the self-assembly. The hexafluorophosphate salt of platinum metallacycle 5b was isolated in $96 \%$ yield and characterized by NMR spectroscopy and ESI-HRMS. Mass spectrometry showed peaks resulting from the loss of between two and five hexafluorophosphate anions. A comparison between the calculated and experimental isotopic mass distribution data for the triply charged species supported the structure of $\left[\mathbf{5 b} \cdot 3 \mathrm{PF}_{6}\right]^{3+}$.

To obtain additional information on the structure and size of compound $\mathbf{5 b}$, this molecule was characterized by means of DFT calculations (B3LYP model). Geometry optimization of $\mathbf{5 b}$ was carried out in water without constrains (see the Supporting Information). The calculated structure evidenced that the rectangular metallacycle is $14.4 \AA$ in length and $6.6 \AA$ width (distances measured between the corresponding centroids of each side). Taking into account the van der Waals radius of an $\operatorname{sp}^{2}$ carbon $(1.7 \AA)$, the size of the resulting cavity is suitable to accommodate a polycyclic aromatic guest. Likewise, the calculated dimensions are very similar to those of the bipyridium analogue $\mathbf{6}^{[10]}$
Complexation of metallacycles $5 \mathrm{a}$ and $5 \mathrm{~b}$ with PAHs: With metallacycles $\mathbf{5 a}$ and $\mathbf{5 b}$ in our hands, we approached a systematic study of their complexes with PAHs, either in solution or solid state. To achieve a representative group, six PAHs with different sizes and shapes were chosen: naphthalene (NAP), anthracene (ANT), phenanthrene (PHE), pyrene (PYR), triphenylene (TRI), and benzo[ $a]$ pyrene (BPY) (Scheme 1). The host-guest interaction in solution was examined by NMR and UV/Vis spectroscopy. The addition of 1 equiv of PYR to a solution of metallacycle $5 \mathbf{a} \cdot 6 \mathrm{NO}_{3}$ in water $(2.5 \mathrm{~mm}$, sonication for $2 \mathrm{~h}$ was necessary to dissolve the PYR) resulted in the appearance of a redcolored solution, originating from a charge-transfer band between the host and guest centered at $\lambda=437 \mathrm{~nm}$. The continuous variation method (Job plot) confirmed the stoichiometry of complex formation between PYR and $\mathbf{5} \mathbf{b} \cdot 6 \mathrm{PF}_{6}$ in $\mathrm{CH}_{3} \mathrm{CN}$ solution to be 1:1 (Figure 2). However, the Job plot for the complexes of BPY and TRI with $\mathbf{5} \mathbf{b} \cdot 6 \mathrm{PF}_{6}$ showed a 2:1 (metallacycle/PAH) stoichiometry. In addition, the titration curves were poorly fitted to a 1:1 binding isotherm, but nicely fitted to a 2:1 binding isotherm (see the Supporting Information).
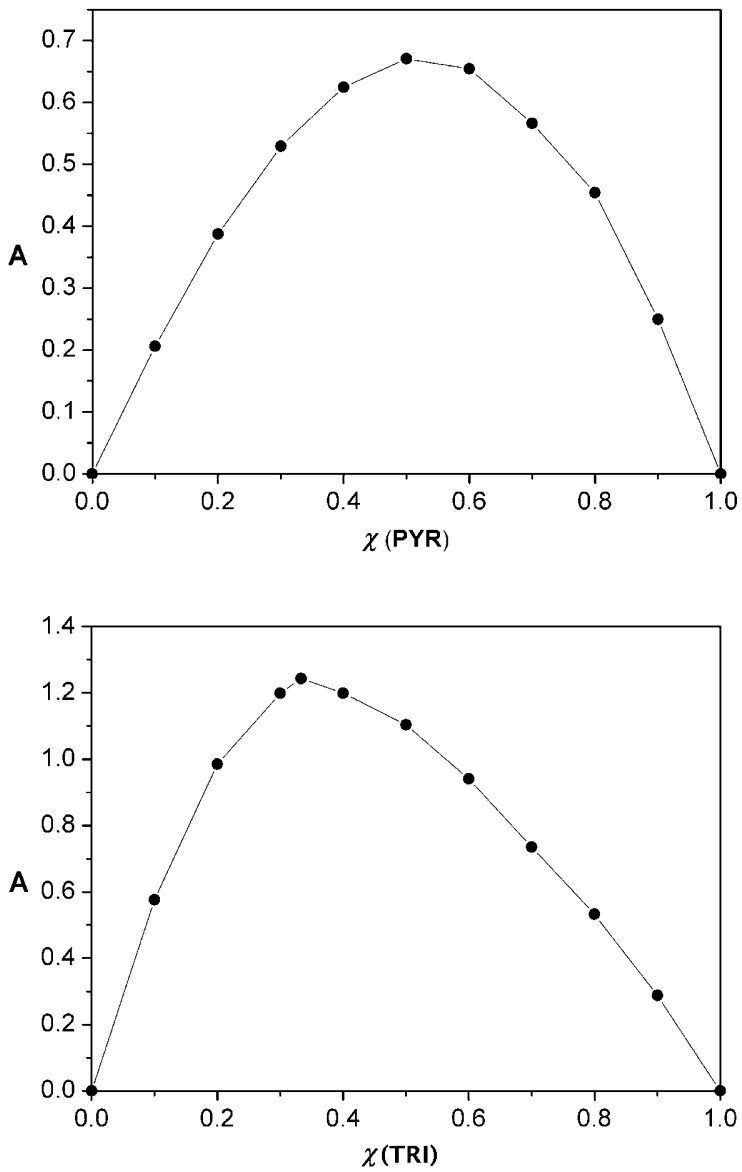

Figure 2. Job plots showing the 1:1 stoichiometry of complex $\mathrm{PYR} \subset \mathbf{5} \mathbf{b} \cdot 6 \mathrm{PF}_{6}$ and 2:1 stoichiometry of TRI $\subset\left(\mathbf{5} \mathbf{b} \cdot 6 \mathrm{PF}_{6}\right)_{2}$ in $\mathrm{CH}_{3} \mathrm{CN}$. 
Table 1. ${ }^{1} \mathrm{H}$ and ${ }^{13} \mathrm{C}$ NMR chemical shift data $(\Delta \delta)$ for metallacycle $\mathbf{5} \mathbf{a} \cdot 6 \mathrm{NO}_{3}(2.5 \mathrm{~mm})$ and complexes $\mathrm{PAH}_{\mathbf{5}} \mathbf{5} \mathbf{a} \cdot 6 \mathrm{NO}_{3}(2.5 \mathrm{~mm})$.

\begin{tabular}{|c|c|c|c|c|c|c|c|c|c|c|c|c|c|c|}
\hline Compound $^{[\mathrm{a}]}$ & $\mathrm{H} / \mathrm{C}$ & a & $\mathrm{b}$ & $\mathrm{c}$ & d & $\mathrm{e} / \mathrm{e}^{\prime}$ & $\mathrm{f} / \mathrm{f}^{\prime}$ & $\mathrm{g} / \mathrm{g}^{\prime}$ & $\mathrm{h} / \mathrm{h}^{\prime}$ & $\mathrm{q}^{[\mathrm{c}]}$ & $\mathrm{r}^{[\mathrm{c}]}$ & $\mathrm{S}^{[\mathrm{c}]}$ & $\mathrm{t}^{[\mathrm{c}]}$ & $\mathrm{v}^{[\mathrm{c}]}$ \\
\hline \multirow{2}{*}{$\mathbf{5} \mathbf{a} \cdot 6 \mathrm{NO}_{3}{ }^{[\mathrm{b}]}$} & ${ }^{1} \mathrm{H}$ & 0.05 & -0.5 & -0.4 & -0.5 & -0.26 & 0.02 & 0.02 & 0.35 & & & & & \\
\hline & ${ }^{13} \mathrm{C}$ & 9.7 & 0 & -1 & -0.7 & 0.8 & 2 & -1.2 & 1.3 & & & & & \\
\hline \multirow{2}{*}{$\mathrm{PYR} \subset \mathbf{5} \mathbf{a} \cdot 6 \mathrm{NO}_{3}$} & ${ }^{1} \mathrm{H}$ & 0.42 & 0.39 & 0.11 & -0.42 & -1.11 & -0.65 & -0.24 & 0.12 & -3.03 & -2.15 & & -1.13 & \\
\hline & ${ }^{13} \mathrm{C}$ & 0.4 & 0.2 & 0 & -1.3 & -3.7 & -0.4 & -0.5 & -0.2 & -1.9 & -1.3 & & -1.1 & \\
\hline \multirow{2}{*}{$\mathrm{PHE} \subset \mathbf{5} \mathbf{a} \cdot 6 \mathrm{NO}_{3}$} & ${ }^{1} \mathrm{H}$ & 0.34 & 0.32 & 0.11 & -0.26 & -0.83 & -0.42 & -0.17 & 0.09 & -3.31 & -2.99 & -2.14 & -1.12 & \\
\hline & ${ }^{13} \mathrm{C}$ & 0.3 & 0.2 & 0.1 & -0.8 & -2.7 & -0.2 & -0.2 & -0.1 & -2.5 & & -1.5 & -3 & -2.8 \\
\hline $\mathrm{TRI} \subset \mathbf{5} \mathbf{a} \cdot 6 \mathrm{NO}_{3}$ & ${ }^{1} \mathrm{H}$ & 0.44 & 0.4 & 0.07 & -0.58 & -1.05 & -0.63 & -0.3 & 0.15 & -1.42 & -2.05 & & & \\
\hline \multirow{2}{*}{$\mathrm{ANT} \subset \mathbf{5} \mathbf{a} \cdot 6 \mathrm{NO}_{3}$} & ${ }^{1} \mathrm{H}$ & 0.34 & 0.36 & 0.17 & -0.11 & -0.99 & -0.5 & -0.19 & 0 & -2.23 & -2.15 & & -1.81 & \\
\hline & ${ }^{13} \mathrm{C}$ & 0.4 & 0.2 & 0.2 & -0.6 & -2.7 & -0.2 & -0.3 & -0.2 & -1.4 & -3.1 & & -2.6 & \\
\hline \multirow{2}{*}{$\mathrm{BPY} \subset \mathbf{5} \mathbf{a} \cdot 6 \mathrm{NO}_{3}{ }^{[\mathrm{d}]}$} & ${ }^{1} \mathrm{H}$ & 0.58 & 0.52 & 0.04 & -0.64 & $-1.14 /-1.35$ & $-0.83 /-0.88$ & $-0.36 /-0.53$ & $0.08 / 0.01$ & & & & & \\
\hline & ${ }^{13} \mathrm{C}$ & 0.7 & 0.5 & 0.1 & -1.8 & $-3.9 /-4.1$ & -0.9 & -0.7 & $-0.4 / 0.1$ & & & & & \\
\hline
\end{tabular}

[a] Hydrogen and carbon labels are defined in Scheme 1 . The $\Delta \delta$ values are compared with those of the free metallacycle $\mathbf{5}$ a $6 \mathrm{NO}_{3}$. [b] The $\Delta \delta$ values for $\mathbf{5} \mathbf{a} \cdot 6 \mathrm{NO}_{3}$ are compared with those of free ligand $\mathbf{3} \cdot \mathrm{NO}_{3}$. [c] The $\Delta \delta$ values are compared with those of free $\mathrm{PAH}$ in $\mathrm{CDCl}$ solution. [d] Twelve resonances from BPY were identified in the ${ }^{1} \mathrm{H}$ NMR spectrum, but they could not be assigned.

The ${ }^{1} \mathrm{H}$ NMR spectra of equimolar solutions of $\mathbf{5} \mathbf{a} \cdot 6 \mathrm{NO}_{3}$ $(2.5 \mathrm{~mm})$ and PAHs in $\mathrm{D}_{2} \mathrm{O}$ recorded upon sonication for $2 \mathrm{~h}$ at room temperature (except for TRI and BPY, which required $20 \mathrm{~h}$ of sonication to complete the inclusion processes) showed signals compatible with the formation of the complexes. The protons of the corresponding PAH were dramatically shielded (for example in the PHE complex: $\Delta \delta=-3.31$ and $-2.99 \mathrm{ppm}$ for $\mathrm{H}_{\mathrm{q}}$ and $\mathrm{H}_{\mathrm{r}}$, respectively) as a consequence of the insertion of the guest. As usual, the protons at the central positions of the long side of the rectangle $\left(\mathrm{H}_{\mathrm{d}-\mathrm{h}}\right)$ are specially shifted upfield, whereas the probable $\mathrm{CH}-\pi$ interactions induce the downfield shift of the protons at the short side (pyridine ring, protons $\mathrm{H}_{\mathrm{a}}$ and $\mathrm{H}_{\mathrm{b}}$; Figure 1c and Table 1). At room temperature, the rate of the equilibrium complexation process for all the PAHs (except NAP) is slow on the NMR spectroscopy time scale. Thus, the addition of an excess of receptor $\mathbf{5} \mathbf{a} \cdot 6 \mathrm{NO}_{3}$ to a solution of PYR $\subset \mathbf{5 a} \cdot 6 \mathrm{NO}_{3}$ allowed us to observe two sets of signals, one for PYR $\subset \mathbf{5 a} \cdot 6 \mathrm{NO}_{3}$ and one attributable to the void metallacycle $5 \mathbf{a} \cdot 6 \mathrm{NO}_{3}$ (Figure 3 ). The same pattern of chemical shifts, but to a lower extent because of fast exchange, can be observed for the complex with NAP. The formation of the inclusion complexes $\mathrm{TRI} \subset \mathbf{5} \mathbf{a} \cdot 6 \mathrm{NO}_{3}$ and $\mathrm{BPY} \subset \mathbf{5} \mathbf{a} \cdot 6 \mathrm{NO}_{3}$ was monitored by ${ }^{1} \mathrm{H}$ NMR spectroscopy. The spectra showed separated signals for the inclusion complexes and the void metallacycle suggesting that the exchange rates are again slow on the NMR spectroscopy time scale. Surprisingly, the complexes of $\mathbf{5} \mathbf{a} \cdot 6 \mathrm{NO}_{3}$ with TRI and BPY presented a 1:1 stoichiometry in $\mathrm{D}_{2} \mathrm{O}$, in contrast to the 2:1 stoichiometry observed in $\mathrm{CH}_{3} \mathrm{CN}$ solution with these guests. The 1:1 stoichiometry was determined on the basis of ${ }^{1} \mathrm{H}$ NMR spectra integration. Even if an excess of metallacycle is present, the $1: 1$ stoichiometry of the complex is preserved. In other words, the ${ }^{1} \mathrm{H}$ NMR spectra recorded while the formation of the inclusion complexes was monitored showed the signals assigned to the inclusion complex integrating according to a 1:1 stoichiometry. Solvent polarity and hydrophobic forces could play a key role in determining the stoichiometry. Probably, in water the guests are completely inserted into the metallacycle and the whole complex

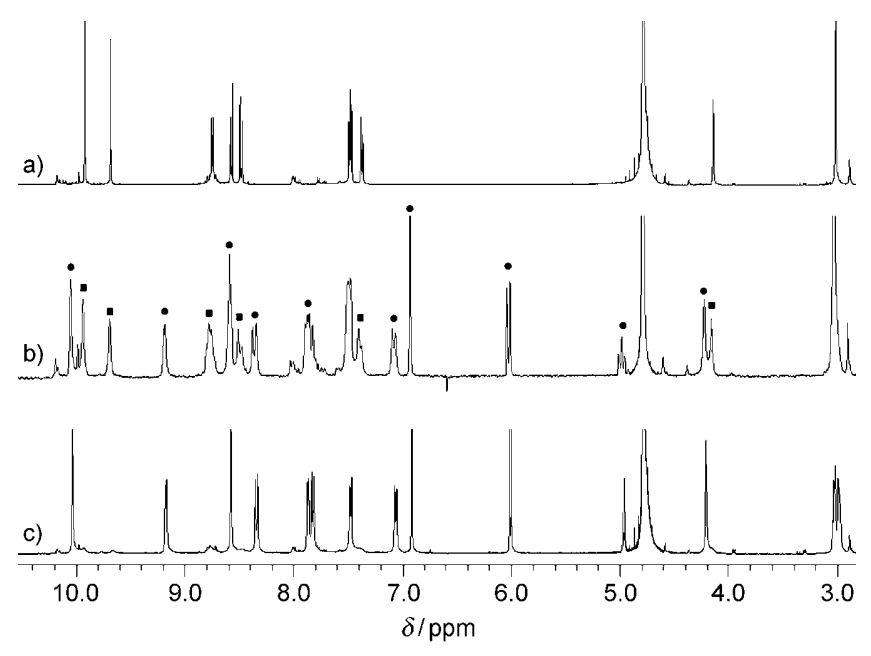

Figure 3. Partial ${ }^{1} \mathrm{H}$ NMR $\left(\mathrm{D}_{2} \mathrm{O}, 500 \mathrm{MHz}\right)$ spectra of a) metallacycle $\mathbf{5} \mathbf{a} \cdot 6 \mathrm{NO}_{3}(2.5 \mathrm{~mm})$, b) a solution of metallacycle $\mathbf{5 a} \cdot 6 \mathrm{NO}_{3}(2.5 \mathrm{~mm})$ and PYR $(0.75 \mathrm{~mm})$, and c) a solution of metallacycle $\mathbf{5} \mathbf{a} \cdot 6 \mathrm{NO}_{3}(2.5 \mathrm{~mm})$ and PYR (2.5 mM). $\quad \boldsymbol{\quad}=$ metallocycle $\quad \mathbf{5} \mathbf{a} \cdot 6 \mathrm{NO}_{3} ; \quad \boldsymbol{\bullet}=$ inclusion complex $\mathrm{PYR} \subset \mathbf{5} \mathbf{a} \cdot 6 \mathrm{NO}_{3}$.

is well solvated, whereas in $\mathrm{CH}_{3} \mathrm{CN}$ solution a partial insertion could induce the formation of a ternary complex. Interestingly, the signals assigned to $\mathrm{H}_{\mathrm{r}}$ and $\mathrm{H}_{\mathrm{q}}$ of the guest in TRI $\subset \mathbf{5} \mathbf{a} \cdot 6 \mathrm{NO}_{3}$ appeared as two double doublets; moreover, only eight resonances for the aromatic protons of the metallacycle were detected. This observation in conjunction with the slow rate exchange indicated that the rotation of TRI around its $\mathrm{C}_{3}$ axis inside the metallacycle is fast on the NMR spectroscopy time scale. Although, the dynamic behavior of $\mathrm{BPY} \subset \mathbf{5} \mathbf{a} \cdot 6 \mathrm{NO}_{3}$ is slightly different, its ${ }^{1} \mathrm{H} \mathrm{NMR}$ spectrum revealed two doublets with a geminal coupling constant $(J=13.0$ and $13.4 \mathrm{~Hz})$ for the methylene group indicating that the equatorial plane of the metallacycle is not a symmetry plane for $\mathrm{BPY} \subset \mathbf{5} \mathbf{a} \cdot 6 \mathrm{NO}_{3}$. Consequently, all the protons of each diazapyrenium moiety are non-equivalent and they appear as eight resonances, suggesting that the rotation of these aromatic systems around the $\mathrm{N}-\mathrm{N}$ axis is 
slow on the ${ }^{1} \mathrm{H}$ NMR spectroscopy time scale (protons e, $\mathrm{e}^{\prime}-$ $h$, h' in Table 1). On the contrary, the rotation of the pyridine and phenylene rings is fast and such splitting of signals was not detected.

The DOSY experiments also supported the complexation, all the signals attributable to the complex, including those of the PAHs resonances, showed the same diffusion coefficient (Figure 4)

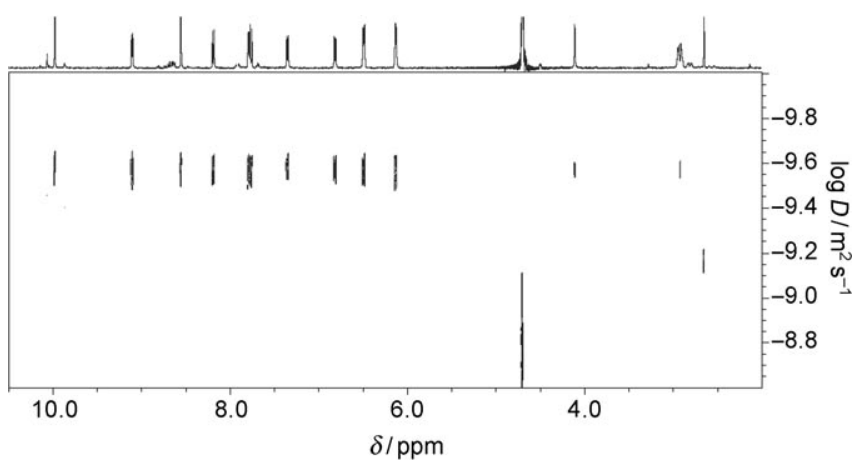

Figure 4. DOSY $\left(\mathrm{D}_{2} \mathrm{O}, 500 \mathrm{MHz}, 298 \mathrm{~K}\right)$ experiment of TRI $\subset \mathbf{5} \mathbf{a} \cdot 6 \mathrm{NO}_{3}$.

The affinity of metallacycle $\mathbf{5} \mathbf{a} \cdot 6 \mathrm{NO}_{3}$ for PAHs in aqueous media was monitored by ${ }^{1} \mathrm{H}$ NMR spectroscopy. Competition assays revealed that NAP and ANT present the lowest affinity because the addition of 1 equivalent of PYR can displace them completely from the cavity of metallacycle $5 \mathbf{a} \cdot 6 \mathrm{NO}_{3}$ (after sonication). The PHE inclusion complex is more stable and PYR can displace PHE only partially (see the Supporting Information). These results are in agreement with the values of the association constants determined in aqueous media (see below).

Crystal structures of $P Y R \subset 5 a \cdot 6 P_{6}, P H E \subset 5 a \cdot 6 P_{6}$, and TRI $\subset 5 \mathbf{a} \cdot \mathbf{6 P F}_{\mathbf{6}}$ : The formation of the 1:1 inclusion complexes with PYR, PHE, and TRI in the solid state was confirmed by X-ray crystallography analysis of single crystals obtained by vapor diffusion of isopropyl ether into $\mathrm{CH}_{3} \mathrm{CN}$ solutions of the corresponding $\mathrm{PAH}$ and $\mathbf{5} \mathbf{a} \cdot 6 \mathrm{PF}_{6}$ (Figure 5). Crystal structures show the inclusion of the PAH inside of the hexacationic metallacycle. The distance between the planes de-

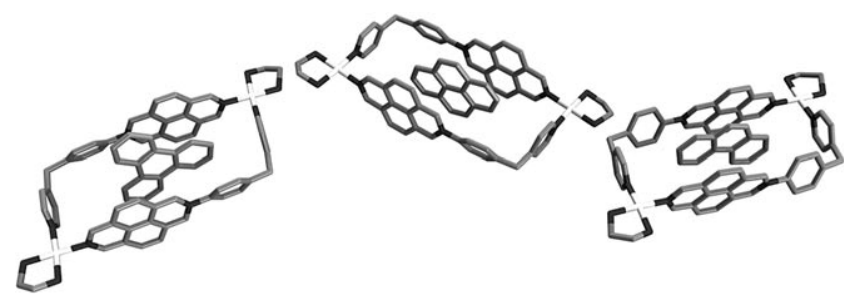

Figure 5. Crystal structures of the inclusion complexes TRI $\subset \mathbf{5} \mathbf{a} \cdot 6 \mathrm{PF}_{6}$, $\mathrm{PYR} \subset \mathbf{5} \mathbf{a} \cdot 6 \mathrm{PF}_{6}$, and $\mathrm{PHE} \subset \mathbf{5 a} \cdot 6 \mathrm{PF}_{6}$ (from left to right). Hydrogen atoms, solvent molecules, and counterions have been omitted for clarity. The color-labeling scheme is as follows: carbon (gray), palladium (light gray), and nitrogen (dark gray). fined by the guest and the diazapirenium moieties is very close to the optimal separation maximizing $\pi-\pi$ interactions. The metallacycle increases slightly its length to about $14.90 \AA$ and reduces the width to about $7.0 \AA$. The planes defined by the diazapyrene systems are parallel to each other and nearly perpendicular to the equatorial plane of the metallacycle defined by their four corners. Possibly, this disposition of the diazapyrene rings also forces the $\mathrm{PAH}$ plane to be orthogonal (about $86^{\circ}$ ) to the same plane, in contrast to the angle measured in PYR $\subset \mathbf{6 a} \cdot 6 \mathrm{NO}_{3}\left(70^{\circ}\right)$ where the diazapyrenium system is replaced by a $4,4^{\prime} \mathrm{bi}$ pyridium one. ${ }^{[10]}$

The position of PYR and PHE inside the cavity deviates slightly from the longitudinal insertion mode defined by the coincidence of the axis $\mathrm{H} 2-\mathrm{H} 7$ and the equatorial plane of $5 \mathbf{a} \cdot 6 \mathrm{PF}_{6}$. The angles formed by this axis and the equatorial plane of the metallacycle are $19^{\circ}$ (PYR) and $15^{\circ}$ (PHE). In the case of TRI $\subset \mathbf{5} \mathbf{a} \cdot 6 \mathrm{PF}_{6}$ the mode of binding in the solid state is close to the longitudinal insertion, being the angle between one of the $\mathrm{C}_{2}$ axes of TRI and the equatorial plane of the metallacycle corresponding to $8^{\circ}$.

Determination of binding constants: To measure the association between metallacycles $5 \mathbf{a}, \mathbf{5} \mathbf{b}$, and $\mathbf{6} \mathbf{a}$ and the selected PAHs quantitatively, the association constants were determined in acetonitrile solution. The results found are summarized in Table 2. As could be expected, the diazapyrene

Table 2. Association constants $K_{\mathrm{a}}\left(\mathrm{L} \mathrm{mol}^{-1} \text { or } \mathrm{Lmol}^{-2}\right)^{[\mathrm{a}]}$ in $\mathrm{CH}_{3} \mathrm{CN}$ for the complexes formed between metallacycles $5 \mathbf{b}$ or $6 \mathbf{a}$ and PAHs.

\begin{tabular}{llllll}
\hline Entry & Metallacycle & PAH & $K_{\mathrm{a}}\left[\mathrm{M}^{-1}\right]$ or $\left[\mathrm{M}^{-2}\right]$ & $\begin{array}{l}\lambda_{\max } \\
{[\mathrm{nm}]}\end{array}$ \\
\hline 1 & $\mathbf{6 a} \cdot 4 \mathrm{OTf} \cdot 2 \mathrm{PF}_{6}$ & pyrene & $145 \pm 7$ & $1: 1$ & 452 \\
2 & $\mathbf{6 a} \cdot 4 \mathrm{OTf} \cdot 2 \mathrm{PF}_{6}$ & phenanthrene & $156 \pm 6$ & $1: 1$ & 425 \\
3 & $\mathbf{6 a} \cdot 4 \mathrm{OTf} \cdot 2 \mathrm{PF}_{6}$ & triphenylene & $376 \pm 10$ & nd & 410 \\
4 & $\mathbf{5 b} \cdot 6 \mathrm{PF}_{6}$ & naphthalene & $<10$ & $1: 1$ & 435 \\
5 & $\mathbf{5 b} \cdot 6 \mathrm{PF}_{6}$ & anthracene & $3135 \pm 82$ & $1: 1$ & 436 \\
6 & $\mathbf{5 b} \cdot 6 \mathrm{PF}_{6}$ & pyrene & $10704 \pm 766$ & $1: 1$ & 437 \\
7 & $\mathbf{5 b} \cdot 6 \mathrm{PF}_{6}$ & phenanthrene & $3426 \pm 121$ & $1: 1$ & 437 \\
8 & $\mathbf{5 b} \cdot 6 \mathrm{PF}_{6}$ & triphenylene & $1.46 \times 10^{7} \pm 3 \times 10^{5}$ & $2: 1$ & 438 \\
9 & $\mathbf{5 b} \cdot 6 \mathrm{PF}_{6}$ & benzo $[a]$ pyrene & $4.19 \times 10^{7} \pm 8 \times 10^{5}$ & $2: 1$ & 438 \\
\hline
\end{tabular}

[a] The association constants reported for TRI and BPY complexes (entries 8 and 9) are the product of $K_{\mathrm{a} 1} \times K_{\mathrm{a} 2}$.

based metallacycle 5b displays higher association constants than the bipyridine metallacycle $\mathbf{6 a}$ for all the PAH measured. Furthermore, the magnitude of the association constants for the 1:1 complexes of $\mathbf{5} \mathbf{b}$ (Table 2, entries 4-7) is well correlated with the size and extended $\pi$ character of the PAHs used in the study.

An important feature of these metallacycles is their ability for the extraction of PAHs to an aqueous phase. The association constants in water were estimated by liquid-liquid extraction experiments and are summarized in Table $3 .^{[14]} \mathrm{A}$ $10 \mathrm{~mm}$ solution of PAH in heptane was extracted for $24 \mathrm{~h}$ at room temperature with a $2 \mathrm{~mm}$ solution of $\mathbf{5} \mathbf{b} \cdot 6 \mathrm{NO}_{3}$. The concentration of PAH in the heptane solution upon extrac- 
Table 3. Association constants $K_{\mathrm{a}}\left(\mathrm{L} \mathrm{mol}^{-1}\right)$ in $\mathrm{H}_{2} \mathrm{O}$ for $1: 1$ complexes formed between metallacycle $\mathbf{5} \mathbf{b} \cdot 6 \mathrm{NO}_{3}$ and PAHs.

\begin{tabular}{llll}
\hline Entry & PAH & $K_{\mathrm{a}}\left[\mathrm{M}^{-1}\right]$ & {$[\mathrm{PAH}]_{\mathrm{H}_{2} \mathrm{O}}[\mathrm{M}]^{[\mathrm{a}]}$} \\
\hline 1 & naphthalene & $2.59 \times 10^{3}$ & $2.47 \times 10^{-4}$ \\
2 & anthracene & nd & $4.10 \times 10^{-7}$ \\
3 & pyrene & $5.59 \times 10^{5}$ & $6.63 \times 10^{-7}$ \\
4 & phenanthrene & $6.47 \times 10^{4}$ & $7.24 \times 10^{-6}$ \\
5 & benzo $[a]$ pyrene & $7.69 \times 10^{6}$ & $1.51 \times 10^{-8}$ \\
\hline
\end{tabular}

[a] Taken from reference [16].

tion $\left([\mathrm{PAH}]_{\text {hep }}\right)$ was determined by GC-MS. The total concentration of pyrene present in the aqueous solution $[\mathrm{PAH}]_{\mathrm{H}_{2} \mathrm{O}(\text { tot })}$ can be calculate by subtracting $[\mathrm{PAH}]_{\text {hep }}$ from the initial concentration of pyrene $(10 \mathrm{~mm})$. It can be assumed that the amount of uncomplexed PAH in the aqueous solution can be considered constant and equal to the maximum concentration of $\mathrm{PAH}$ in water $\left([\mathrm{PAH}]_{\mathrm{H}_{2} \mathrm{O}}\right) \cdot{ }^{[5]}$ The concentration of $\mathrm{PAH}$ complexed is $[\mathrm{PAH}]_{\mathrm{H}_{2} \mathrm{O}(\mathrm{tot})}-$ $[\mathrm{PAH}]_{\mathrm{H}_{2} \mathrm{O}}$, which in a 1:1 complexation is equal to the concentration of $\left[\mathrm{PAH} \subset \mathbf{5} \mathbf{b} \cdot 6 \mathrm{NO}_{3}\right]_{\mathrm{H}_{2} \mathrm{O}}$. The concentration of free metallacycle is obtained by subtracting $\left[\mathrm{PAH} \subset \mathbf{5} \mathbf{b} \cdot 6 \mathrm{NO}_{3}\right]_{\mathrm{H}_{2} \mathrm{O}}$ from the initial concentration of $\mathbf{5} \mathbf{b} \cdot 6 \mathrm{NO}_{3}(2 \mathrm{~mm})$. Therefore, all concentrations of equation (1) are known and $K_{\mathrm{a}}$ is determined from equation (2)

$$
\begin{aligned}
& \left(\mathbf{5} \mathbf{b} \cdot 6 \mathrm{NO}_{3}\right)_{\mathrm{H}_{2} \mathrm{O}}+\mathrm{PAH}_{\mathrm{H}_{2} \mathrm{O}} \rightleftharpoons\left(\mathrm{PAH} \subset \mathbf{5 a} \cdot 6 \mathrm{NO}_{3}\right)_{\mathrm{H}_{2} \mathrm{O}} \\
& K_{\mathrm{a}}=\frac{\left[\mathrm{PAH} \subset \mathbf{5} \mathbf{b} \cdot 6 \mathrm{NO}_{3}\right]_{\mathrm{H}_{2} \mathrm{O}}}{\left[\mathbf{5 b} \cdot 6 \mathrm{NO}_{3}\right]_{\mathrm{H}_{2} \mathrm{O}}[\mathrm{PAH}]_{\mathrm{H}_{2} \mathrm{O}}}
\end{aligned}
$$

The association constants in aqueous media show a clear correlation with the hydrophobicity of the PAH. The larger the aromatic surface, the greater the association constant for its formation. Finally, a series of competitive extraction experiments was carried out to illustrate the selectivity of this molecular recognition process. On one hand, PYR was exclusively extracted from a 1:1 molar mixture of PYR/NAP. On the other hand, a slight excess of PYR (54\% molar) was extracted to the aqueous phase from an equimolar solution of PYR and PHE, according to the respective binding constants and structural similarity between PYR and PHE. Similarly, a correspondence was found between association constants and the molar extraction of an equimolar solution of five PAHs (NAP, 9\%; ANT, 19\%; PHE, 20\%; PYR, $21 \%$; BPY, $31 \%)$.

\section{Conclusion}

New dinuclear metallacycles were self-assembled in aqueous media from a 2,7-diazapyrenium-based ligand and squareplanar palladium(II) or platinum(II) complexes. These rectangular metallacycles have proven to be receptors for PAHs, such as pyrene, phenanthrene, triphenylene, and benzo $[a]$ pyrene. Their cavities present a nearly optimal size to form supramolecular complexes with PAHs through $\pi$-stacking and hydrophobic forces. The crystal structures of three inclusion complexes (with PYR, PHE, and TRI) have been presented and discussed. The association constants of platinum receptor $\mathbf{5 b}$ with PAHs in organic and aqueous media were measured. The potential of the designed metallacycle $\mathbf{5 b}$, for the selective extraction of PAHs from an organic media to an aqueous phase, was explored by means of competitive extraction experiments. The obtained results showed a good correlation between the association constants in water for the inclusion complexes and the resulting percentages of PAHs extracted.

\section{Experimental Section}

Compounds $\mathbf{1},{ }^{[17]} \mathbf{2},{ }^{[18]} \mathbf{6},{ }^{[9]}$ and 2,7-diazapyrene ${ }^{[19]}$ were prepared according to published procedures. All other reagents used were commercial grade chemicals from freshly opened containers. Milli-Q water was purified with a Millipore Gradient A10 apparatus. Merck $60 \mathrm{~F}_{254}$ foils were used for thin layer chromatography, and Merck 60 (230-400 mesh) silica gel was used for flash chromatography. Proton and carbon nuclear magnetic resonance spectra were recorded on a Bruker Avance 300 or Bruker Avance 500 spectrometer equipped with a dual cryoprobe for ${ }^{1} \mathrm{H}$ and ${ }^{13} \mathrm{C}$, using the deuterated solvent as lock and the residual protiated solvent as internal standard. DOSY experiments were referenced using the value $1.92 \times 10^{-9} \mathrm{~m}^{2} \mathrm{~s}^{-1}$ for the DHO signal in $\mathrm{D}_{2} \mathrm{O}$ at $298 \mathrm{~K}^{[20]}$ and the value $1.97 \times 10^{-9} \mathrm{~m}^{2} \mathrm{~s}^{-1}$ for the $\mathrm{CHD}_{2} \mathrm{NO}_{2}$ signal in $\mathrm{CD}_{3} \mathrm{NO}_{2}$ at 298 K. ${ }^{[21]}$ Mass spectrometry experiments were carried out in an LC-Q-qTOF Applied Biosystems QSTAR Elite spectrometer for low- and highresolution ESI. Determinations of PAH by GCMS were carried out in a Thermo Finnigan Polaris Q system equipped with a J\&W, DB-XLB column.

Ligand 3.PF $\mathbf{F}_{\mathbf{6}}$ : A solution of 2-(2,4-dinitrobenzyl)-2,7-diazapiren-2-ium chloride (1. Cl) $(1.03 \mathrm{~g}, 2.77 \mathrm{mmol})$ and 4-(pyridin-4-ylmethyl)aniline (2) $(2.04 \mathrm{~g}, 11.07 \mathrm{mmol})$ in EtOH $(75 \mathrm{~mL})$ was refluxed for $3 \mathrm{~d}$, after cooling, the solvent was evaporated in vacuo. The resulting residue was dissolved in $\mathrm{H}_{2} \mathrm{O}(200 \mathrm{~mL})$ and extracted with EtOAc $(200 \mathrm{~mL})$. The organic layer was further extracted with $\mathrm{H}_{2} \mathrm{O}(2 \times 150 \mathrm{~mL})$ and the combined aqueous extracts were washed with EtOAc $(4 \times 75 \mathrm{~mL})$. The solvent was removed under reduced pressure to give a crude product, which was purified by column chromatography $\left(\mathrm{SiO}_{2}\right.$, acetone $\left./ \mathrm{NH}_{4} \mathrm{Cl} 1.5 \mathrm{M} / \mathrm{MeOH} 5: 4: 1\right)$. The product-containing fractions were combined and the solvents were removed in vacuo. The residue was dissolved in $\mathrm{H}_{2} \mathrm{O} / \mathrm{CH}_{3} \mathrm{OH}$ (95:5, $250 \mathrm{~mL}$ ) and an excess of $\mathrm{KPF}_{6}$ was added until no further precipitation was observed. The solid was filtered and washed with water to give $3 \cdot \mathrm{PF}_{6}$ $(0.97 \mathrm{~g}, 70 \%)$ as a dark yellow solid. ${ }^{1} \mathrm{H} \mathrm{NMR}\left(500 \mathrm{MHz}, \mathrm{CD}_{3} \mathrm{NO}_{2}\right): \delta=$ $4.68(\mathrm{~s}, 2 \mathrm{H}), 7.84(\mathrm{~d}, J=8.6 \mathrm{~Hz}, 2 \mathrm{H}), 8.08(\mathrm{~d}, J=8.6 \mathrm{~Hz}, 2 \mathrm{H}), 8.11(\mathrm{~d}, J=$ $6.7 \mathrm{~Hz}, 2 \mathrm{H}), 8.69(\mathrm{~d}, J=9.1 \mathrm{~Hz}, 2 \mathrm{H}), 8.82(\mathrm{~d}, J=6.8 \mathrm{~Hz}, 2 \mathrm{H}), 8.84(\mathrm{~d}, J=$ $9.1 \mathrm{~Hz}, 2 \mathrm{H}), 9.91(\mathrm{~s}, 2 \mathrm{H}), 9.92 \mathrm{ppm}(\mathrm{s}, 2 \mathrm{H}) ;{ }^{13} \mathrm{C} \mathrm{NMR}(125 \mathrm{MHz}$, $\left.\mathrm{CD}_{3} \mathrm{NO}_{2}\right): \delta=42.1\left(\mathrm{CH}_{2}\right), 125.5(\mathrm{C}), 127.2(\mathrm{CH}), 127.3(\mathrm{CH}), 127.6(\mathrm{C})$, $129.3(\mathrm{CH}), 130.4(\mathrm{C}), 130.6(\mathrm{C}), 133.1(\mathrm{CH}), 133.2(\mathrm{CH}), 139.3(\mathrm{CH})$, $142.5(\mathrm{CH}), 142.7(\mathrm{C}), 144.8(\mathrm{C}), 149.9(\mathrm{CH}) ; \mathrm{MS}(\mathrm{ESI}): \mathrm{m} / z: 372.2$ $\left[M-\mathrm{PF}_{6}^{-}\right]^{+}$; elemental analysis calcd $(\%)$ for $\mathrm{C}_{26} \mathrm{H}_{18} \mathrm{~F}_{6} \mathrm{~N}_{3} \mathrm{P}: \mathrm{C} 60.35, \mathrm{H}$ 3.51, N 8.12; found: C 60.08, H 3.86, N 8.33.

Ligand 3. $\mathbf{N O}_{3}$ : Ligand $3 \cdot \mathrm{PF}_{6}(500.0 \mathrm{mg}, 0.97 \mathrm{mmol})$ was dissolved in the minimum amount of $\mathrm{CH}_{3} \mathrm{CN}$ and an excess of $\mathrm{Bu}_{4} \mathrm{NNO}_{3}$ was added until no further precipitation was observed. The white precipitate was filtered and washed with $\mathrm{CH}_{3} \mathrm{CN}$ to yield $3 \cdot \mathrm{NO}_{3}(356.0 \mathrm{mg}, 85 \%)$ as a brown solid. ${ }^{1} \mathrm{H}$ NMR $\left(500 \mathrm{MHz}, \mathrm{D}_{2} \mathrm{O}\right): \delta=4.56(\mathrm{~s}, 2 \mathrm{H}), 7.77(\mathrm{~d}, J=8.5 \mathrm{~Hz}$, $2 \mathrm{H},), 7.98(\mathrm{~m}, 4 \mathrm{H}), 8.46(\mathrm{~d}, J=9.1 \mathrm{~Hz}, 2 \mathrm{H}), 8.56(\mathrm{~d} J=9.1 \mathrm{~Hz}, 2 \mathrm{H}), 8.70$ $(\mathrm{d}, J=6.8 \mathrm{~Hz}, 2 \mathrm{H}), 9.57(\mathrm{~s}, 2 \mathrm{H}), 9.95 \mathrm{ppm}(\mathrm{s}, 2 \mathrm{H}) ;{ }^{13} \mathrm{C} \mathrm{NMR}(125 \mathrm{MHz}$, $\left.\mathrm{D}_{2} \mathrm{O}\right): \delta=40.5\left(\mathrm{CH}_{2}\right), 123.9(\mathrm{C}), 125.5(\mathrm{CH}), 126.1(\mathrm{CH}), 126.2(\mathrm{C}), 127.3$ $(\mathrm{CH}), 128.0(\mathrm{C}), 128.7(\mathrm{C}), 131.0(\mathrm{CH}), 131.6(\mathrm{CH}), 138.2(\mathrm{CH}), 141.1$ (C), $141.2(\mathrm{CH}), 142.6(\mathrm{C}), 146.8(\mathrm{CH}), 161.5 \mathrm{ppm}(\mathrm{C})$; MS (ESI): $\mathrm{m} / \mathrm{z}$ : $372.2\left[M-\mathrm{NO}_{3}^{-}\right]^{+}$; elemental analysis calcd (\%) for $\mathrm{C}_{26} \mathrm{H}_{18} \mathrm{~N}_{4} \mathrm{O}_{3}: \mathrm{C} 71.88$, H 4.18, N 12.90; found: C 71.60, H 3.88, N 13.20 . 
Table 4. Summary of crystal data, intensity measurements, and structure refinement.

\begin{tabular}{|c|c|c|c|}
\hline & $\mathrm{PYR} \subset \mathbf{5} \mathbf{a} \cdot 6 \mathrm{PF}_{6}$ & $\mathrm{PHE} \subset \mathbf{5} \mathbf{a} \cdot 6 \mathrm{PF}_{6}$ & $\mathrm{TRI} \subset \mathbf{5} \mathbf{a} \cdot 6 \mathrm{PF}_{6}$ \\
\hline formula & $\mathrm{C}_{91} \mathrm{H}_{86} \mathrm{~F}_{36} \mathrm{~N}_{20} \mathrm{P}_{6} \mathrm{Pt}_{2}$ & $\mathrm{C}_{39} \mathrm{H}_{36} \mathrm{~F}_{18} \mathrm{~N}_{7} \mathrm{P}_{3} \mathrm{Pt}$ & $\mathrm{C}_{46} \mathrm{H}_{45.5} \mathrm{~F}_{18} \mathrm{~N}_{9.5} \mathrm{P}_{3} \mathrm{Pt}$ \\
\hline$M_{\mathrm{r}}$ & 2719.80 & 1232.75 & 1361.42 \\
\hline $\begin{array}{l}\text { wavelength } \\
\text { [尺] }\end{array}$ & 0.71073 & 0.71073 & 0.71073 \\
\hline $\begin{array}{l}\text { crystal size } \\
{\left[\mathrm{mm}^{3}\right]}\end{array}$ & $0.50 \times 0.32 \times 0.27$ & $0.25 \times 0.06 \times 0.03$ & $0.22 \times 0.15 \times 0.10$ \\
\hline $\begin{array}{l}\text { crystal } \\
\text { system }\end{array}$ & monoclinic & triclinic & monoclinic \\
\hline space group & $C 2 / c$ & $\bar{P} 1$ & $C c$ \\
\hline$a[\AA]$ & $41.102(5)$ & $12.359(5)$ & $41.335(3)$ \\
\hline$b[\AA]$ & $11.488(5)$ & $13.052(5)$ & $11.5259(8)$ \\
\hline$c[\AA]$ & $28.310(5)$ & $15.650(5)$ & $28.6254(19)$ \\
\hline$\alpha\left[^{\circ}\right]$ & $90.000(5)$ & $96.747(5)$ & 90 \\
\hline$\beta\left[^{\circ}\right]$ & $128.761(5)$ & $105.968(5)$ & $129.298(3)$ \\
\hline$\gamma\left[^{\circ}\right]$ & $90.000(5)$ & $110.945(5)$ & 90 \\
\hline$V\left[\AA^{3}\right]$ & $10423(5)$ & $2200.3(14)$ & $10553.8(12)$ \\
\hline$Z$ & 4 & 2 & 8 \\
\hline $\begin{array}{l}\rho_{\text {calcd }} \\
{\left[\mathrm{Mg} \mathrm{m}^{-3}\right]}\end{array}$ & 1.733 & 1.861 & 1.714 \\
\hline$\mu\left[\mathrm{mm}^{-1}\right]$ & 2.894 & 3.415 & 2.858 \\
\hline$\theta$ range $\left[{ }^{\circ}\right]$ & 2.27 to 28.35 & 2.27 to 28.47 & 1.43 to 25.15 \\
\hline index range & $\begin{array}{l}-54 \leq h \leq 46 \\
-15 \leq k \leq 15 \\
-37 \leq l \leq 37\end{array}$ & $\begin{array}{l}-16 \leq h \leq 16 \\
-17 \leq k \leq 17 \\
-20 \leq l \leq 20\end{array}$ & $\begin{array}{l}-49 \leq h \leq 49 \\
-13 \leq k \leq 13 \\
-34 \leq l \leq 34\end{array}$ \\
\hline$T[\mathrm{~K}]$ & $100(2)$ & $100(2)$ & $100(2)$ \\
\hline independent & 12898 & 11046 & 18669 \\
\hline reflections & {$\left[R_{\mathrm{int}}=0.0308\right]$} & {$\left[R_{\mathrm{int}}=0.0310\right]$} & {$\left[R_{\mathrm{int}}=0.0483\right]$} \\
\hline $\begin{array}{l}\text { refinement } \\
\text { method }\end{array}$ & based on $F^{2}$ & based on $F^{2}$ & based on $F^{2}$ \\
\hline $\begin{array}{l}\text { final } R \\
\text { indices } \\
{[I>2 \sigma(I)]}\end{array}$ & $\begin{array}{l}R_{1}=0.0496, \\
w R_{2}=0.1334\end{array}$ & $\begin{array}{l}R_{1}=0.0334, \\
w R_{2}=0.0856\end{array}$ & $\begin{array}{l}R_{1}=0.0432, \\
w R_{2}=0.1106\end{array}$ \\
\hline $\begin{array}{l}R \text { indices } \\
\text { (all data) }\end{array}$ & $\begin{array}{l}R_{1}=0.0560 \\
w R_{2}=0.1386\end{array}$ & $\begin{array}{l}R_{1}=0.0348, \\
w R_{2}=0.0864\end{array}$ & $\begin{array}{l}R_{1}=0.0539 \\
w R_{2}=0.1212\end{array}$ \\
\hline
\end{tabular}

Metallacycle 5b $\mathbf{6} \mathbf{P} \mathbf{F F}_{\mathbf{6}}$ : A solution of ligand $3 \cdot \mathrm{NO}_{3}(120.0 \mathrm{mg}, 0.276 \mathrm{mmol})$ and (en) $\mathrm{Pt}\left(\mathrm{NO}_{3}\right)_{2}$ (4b) $(104.7 \mathrm{mg}, 0.276 \mathrm{mmol})$ in $\mathrm{H}_{2} \mathrm{O}(60 \mathrm{~mL})$ was heated at $100^{\circ} \mathrm{C}$ for $8 \mathrm{~d}$. Upon cooling to room temperature, an excess of $\mathrm{KPF}_{6}$ was added until no further precipitation was observed. The solid was filtered to yield $\mathbf{5 b} \cdot 6 \mathrm{PF}_{6}(281.7 \mathrm{mg}, 96 \%)$ as a brown solid. ${ }^{1} \mathrm{H}$ NMR $\left(500 \mathrm{MHz}, \mathrm{CD}_{3} \mathrm{NO}_{2}\right): \delta=3.19(\mathrm{~m}, 8 \mathrm{H}), 4.26(\mathrm{~s}, 4 \mathrm{H}), 7.42(\mathrm{~d}, J=8.6 \mathrm{~Hz}$, $4 \mathrm{H}), 7.51(\mathrm{~d}, J=6.8 \mathrm{~Hz}, 4 \mathrm{H}), 7.63(\mathrm{~d}, J=8.7 \mathrm{~Hz}, 4 \mathrm{H}), 8.63(\mathrm{~d}, J=9.2 \mathrm{~Hz}$, $4 \mathrm{H}), 8.67(\mathrm{~d}, J=9.2 \mathrm{~Hz}, 4 \mathrm{H}), 8.82(\mathrm{~d}, J=6.8 \mathrm{~Hz}, 4 \mathrm{H}), 9.69(\mathrm{~s}, 4 \mathrm{H})$, $10.00 \mathrm{ppm}(\mathrm{s}, 4 \mathrm{H}) ;{ }^{13} \mathrm{C}$ NMR $\left(125 \mathrm{MHz}, \mathrm{CD}_{3} \mathrm{NO}_{2}\right): \delta=41.1\left(\mathrm{CH}_{2}\right), 49.8$ $\left(\mathrm{CH}_{2}\right), 49.9\left(\mathrm{CH}_{2}\right), 126.2(\mathrm{C}), 126.3(\mathrm{CH}), 128.9(\mathrm{C}), 129.5(\mathrm{CH}), 130.0$ $(\mathrm{CH}), 130.4(\mathrm{C}), 130.7(\mathrm{C}), 131.6(\mathrm{CH}), 132.3(\mathrm{CH}), 140.5(\mathrm{CH}), 143.6$ (C), 144.7 (C), $151.1(\mathrm{CH}), 153.6(\mathrm{CH}), 156.7 \mathrm{ppm}(\mathrm{C})$; HRMS (ESI): $\mathrm{m} / \mathrm{z}$ : calcd for $\left[M-2 \mathrm{PF}_{6}{ }^{-}\right]^{2+} 917.1114$; found 917.1085 ; calcd for $\left[M-3 \mathrm{PF}_{6}{ }^{-}\right]^{3+} 563.0860$; found 563.0853; calcd for $\left[M-4 \mathrm{PF}_{6}{ }^{-}\right]^{4+} 386.0733$; found 386.0749 ; calcd for $\left[M-5 \mathrm{PF}_{6}{ }^{-}\right]^{5+} 279.8657$; found 279.8671 ; elemental analysis calcd (\%) for $\mathrm{C}_{56} \mathrm{H}_{52} \mathrm{~F}_{36} \mathrm{~N}_{10} \mathrm{P}_{6} \mathrm{Pt}_{2}$ : C 31.65, H 2.47, N 6.59; found: C 31.84, H 2.19, N 6.33 .

Metallacycle 5b·6NO : Metallacycle $\mathbf{5 b} \cdot 6 \mathrm{PF}_{6}\left(95.0 \mathrm{mg}, 4.45 \times 10^{-5} \mathrm{mmol}\right)$ was dissolved in the minimum amount of $\mathrm{CH}_{3} \mathrm{CN}$ and an excess of $\mathrm{Bu}_{4} \mathrm{NNO}_{3}$ was added until no further precipitation was observed. The white precipitate was filtered and washed with $\mathrm{CH}_{3} \mathrm{CN}$ to yield $\mathbf{5} \mathbf{b} \cdot 6 \mathrm{NO}_{3}$ (72.5 mg, 99\%) as a brown solid. ${ }^{1} \mathrm{H}$ NMR $\left(500 \mathrm{MHz}, \mathrm{D}_{2} \mathrm{O}\right): \delta=2.93$ (m, $8 \mathrm{H}), 4.16(\mathrm{~s}, 4 \mathrm{H}), 7.39(\mathrm{~d}, J=8.6 \mathrm{~Hz}, 4 \mathrm{H}), 7.48(\mathrm{~m}, 8 \mathrm{H}), 8.50(\mathrm{~d}, J=$ $9.2 \mathrm{~Hz}, 4 \mathrm{H}), 8.57$ (d, $J=9.2 \mathrm{~Hz}, 4 \mathrm{H}), 8.78$ (d, $J=6.8 \mathrm{~Hz}, 4 \mathrm{H}), 9.70$ (s, $4 \mathrm{H}), 9.95 \mathrm{ppm}(\mathrm{s}, 4 \mathrm{H}) ;{ }^{13} \mathrm{C}$ NMR $\left(125 \mathrm{MHz}, \mathrm{D}_{2} \mathrm{O}\right): \delta=39.8\left(\mathrm{CH}_{2}\right), 47.6$ $\left(\mathrm{CH}_{2}\right), 47.6\left(\mathrm{CH}_{2}\right), 124.8(\mathrm{CH}), 125.0(\mathrm{C}), 127.3(\mathrm{C}), 127.7(\mathrm{CH}), 128.1$ $(\mathrm{CH}), 128.8(\mathrm{C}), 129.0(\mathrm{C}), 129.7(\mathrm{CH}), 130.6(\mathrm{CH}), 139.0(\mathrm{CH}), 141.8$ (C), $142.7(\mathrm{C}), 149.0(\mathrm{CH}), 151.6(\mathrm{CH}), 155.1 \mathrm{ppm}(\mathrm{C})$; elemental analysis calcd (\%) for $\mathrm{C}_{56} \mathrm{H}_{52} \mathrm{~N}_{16} \mathrm{O}_{18} \mathrm{Pt}_{2}$ : C 41.33, H 3.22, N 13.77; found: C 41.56, H 3.08, N 13.67.

Computational methods: All calculations were performed using the Gaussian 09 (Revision A.02) ${ }^{[22]}$ program package with the B3LYP ${ }^{[23,24]}$ three-parameter hybrid density functional. Geometry optimization of $\mathbf{5 b}$ was carried out in water without constrains. Initial geometries were constructed using the GaussView program ${ }^{[25]}$ and standard bond distances and angles. In these calculations we used the standard 6-31G(d) basis set for $\mathrm{C}, \mathrm{H}$, and $\mathrm{N}$ atoms, whereas for $\mathrm{Pt}$ atoms the effective core potential of Wadt and Hay (Los Alamos ECP) included in the LanL2DZ basis set was applied. ${ }^{[26]}$ The stationary point found on the potential energy surface as a result of the geometry optimizations of $\mathbf{5 b}$ has been tested to represent energy minima rather than saddle points by frequency analysis. Crystal structure analysis: CCDC-783769, 783767, 783766, and 783768 contain the supplementary crystallographic data for $\mathbf{3} \cdot \mathrm{PF}_{6}$, $\mathrm{PYR} \subset \mathbf{5} \mathbf{a} \cdot 6 \mathrm{PF}_{6}, \mathrm{PHE} \subset \mathbf{5 a} \cdot 6 \mathrm{PF}_{6}$, and $\mathrm{TRI} \subset \mathbf{5} \mathbf{a} \cdot 6 \mathrm{PF}_{6}$, respectively. These data can be obtained free of charge from The Cambridge Crystallographic Data Centre via www.ccdc.cam.ac.uk/data request/cif. Crystal data are reported in Table 4 . The structures were solved by direct methods and refined with the full-matrix least-squares procedure (SHELX-97) ${ }^{[27]}$ against $F^{2}$. The X-ray diffraction data were collected on a Bruker X8 ApexII diffractometer. Non-solvent hydrogen atoms were placed in idealized positions with $U_{\text {eg }}(\mathrm{H})=1.2 U_{\text {eg }}(\mathrm{C})$ and were allowed to ride on their parent atoms. Solvent hydrogen atoms were placed in idealized positions with $U_{\text {eg }}(\mathrm{H})=1.5 U_{\text {eg }}(\mathrm{C})$ and were allowed to ride on their parent atoms.

\section{Acknowledgements}

This research was supported by Ministerio Ciencia e Innovación and FEDER (CTQ2007-63839/BOU, and CTQ2010-16484/BOU). V.B. and E.P. thank Ministerio de Educación (FPU Program) and Universidade da Coruña for predoctoral fellowships. M.D.G. thanks the Xunta de Galicia for financial support under "Programa Isidro Parga Pondal".

[1] a) J. C. Fetzer, The Chemistry and Analysis of the Large Polycyclic Aromatic Hydrocarbons, Wiley, New York, 2000; b) K. Srogi, Environ. Chem. Lett. 2007, 5, 169-195.

[2] a) C. E. Cerniglia, Biodegradation 1992, 3, 351-368; b) P. Y Cheung, B. K. Kinkle, Appl. Environ. Microbiol. 2001, 67, 2222 2229 ; c) D. Dean-Ross, C. E. Cerniglia, Appl. Microbiol. Biotechnol. 1996, 46, 307-312.

[3] a) A. Luch, The Carcinogenic Effects of Polycyclic Aromatic Hydrocarbons, Imperial College Press, London, 2005; b) Q. Lan, M. Shen, S. I. Berndt, M. R. Bonner, X. He, M. Yeager, R. Welch, P. Keohavong, M. Donahue, P. Hainaut, S. Chanock, Lung Cancer 2005, 49, 317-323; c) J. G. Brody, K. B. Moysich, O. Humblet, K. R. Attfield, G. P. Beehler, R. A. Rudel, Cancer 2007, 109, 2667-2711; d) D. M. DeMarini, S. Landi, D. Tian, N. M. Hanley, X. Li, F. Hu, B. C. Roop, M. J. Mass, P. Keohavong, W. Gao, M. Olivier, P. Hainaut, J. L. Mumford, Cancer Res. 2001, 61, 6679-6681.

[4] a) B. J. Reid, J. D. Stokes, K. C. Jones, K. T. Semple, Environ. Sci. Technol. 2000, 34, 3174-3179; b) K. A. Udachin, J. A. Ripmeester, J. Am. Chem. Soc. 1998, 120, 1080-1081.

[5] a) G. F. Swiegers, T. J. Malefetse, Chem. Rev. 2000, 100, 3483-3537; b) M. Fujita, M. Tominaga, A. Hori, B. Therrien, Acc. Chem. Res. 2005, 38, 369-378; c) P. H. Dinolfo, J. T. Hupp, Chem. Mater. 2001, 13, 3113-3125; d) D. L. Caulder, K. N. Raymond, J. Chem. Soc. Dalton Trans. 1999, 1185-1200; e) P. J. Steel, Acc. Chem. Res. 2005 38, 243-250; f) M. Fujita, Chem. Soc. Rev. 1998, 27, 417-425; g) S. Leininger, B. Olenyuk, P. J. Stang, Chem. Rev. 2000, 100, 853-908; h) B. Holliday, C. A. Mirkin, Angew. Chem. 2001, 113, 2076-2097; Angew. Chem. Int. Ed. 2001, 40, 2022-2043; i) F. Würthner, C.-C. You C. R. Saha-Möller, Chem. Soc. Rev. 2004, 33, 133-146; j) J.-P. Collin, V. Heitz, S. Bonnet, J.-P. Sauvage, Inorg. Chem. Commun. 2005, 8, 1063-1074. 
[6] a) Molecular Catenanes, Rotaxanes and Knots, A Journey Through the World of Molecular Topology (Eds.. J.-P. Sauvage, C. DietrichBuchecker), Wiley-VCH, Weinheim, 1999; b) R. F. Carina, C. Dietrich-Buchecker, J.-P. Sauvage, J. Am. Chem. Soc. 1996, 118, 91109116; c) C. P. McArdle, J. J. Vittal, R. J. Puddephatt, Angew. Chem. 2000, 112, 3977-3980; Angew. Chem. Int. Ed. 2000, 39, 3819-3822; d) K. S. Chichak, S. J. Cantrill, A. R. Pease, S.-H. Chiu, G. W. V. Cave, J. L. Atwood, J. F. Stoddart, Science 2004, 304, 1308-1312; e) C. Peinador, V. Blanco, J. M. Quintela, J. Am. Chem. Soc. 2009, 131, 920-921.

[7] a) G. Tárkányi, H. Jude, G. Pálinkás, P. J. Stang, Org. Lett. 2005, 7, 4971-4973; b) D. E. Janzen, K. N. Patel, D. G. VanDerveer, G. J. Grant, Chem. Commun. 2006, 3540-3542; c) Z.-Q. Wu, X.-K. Jiang, Z.-T. Li, Tetrahedron Lett. 2005, 46, 8067-8070; d) C. S. CamposFernández, B. L. Schottel, H. T. Chifotides, J. K. Bera, J. Bacsa, J. M. Koomen, D. H. Russell, K. R. Dunbar, J. Am. Chem. Soc. 2005, 127, 12909-12923; e) H. Jiang, W. Lin, J. Am. Chem. Soc. 2003, 125 8084-8085; f) Y. L. Cho, H. Uh, S.-Y. Chang, H.-Y. Chang, M.-G. Choi, I. Shin, K.-S. Jeong, J. Am. Chem. Soc. 2001, 123, 1258-1259; g) S.-S. Sun, C. L. Stern, S. T. Nguyen, J. T. Hupp, J. Am. Chem. Soc. 2004, 126, 6314-6326; h) Z. Qin, M. C. Jennings, R. J. Puddephat, Inorg. Chem. 2002, 41, 3967-3974; i) F. A. Cotton, C. Lin, C. A. Murillo, Inorg. Chem. 2001, 40, 478-484; j) E. Stulz, S. M. Scott, A. D. Bond, S. J. Teat, J. K. M. Sanders, Chem. Eur. J. 2003, 9, 6039-6048.

[8] a) P. Thanasekaran, R.-T. Liao, Y.-H. Liu, T. Rajendran, S. Rajagopal, K.-L. Lu, Coord, Chem. Rev. 2005, 105, 1085-1110; b) P. S. Mukherjee, K. S. Min, A. M. Arif, P. J. Stang, Inorg. Chem. 2004, 43, 6345-6350; c) K.-S. Jeong, Y. L. Cho, S.-Y. Chang, T.-Y. Park, J. U. Song, J. Org. Chem. 1999, 64, 9459-9466; d) R. Lin, J. H. K. Yip, K. Zhang, L. L. Koh, K.-Y. Wong, K. P. Ho, J. Am. Chem. Soc. 2004 126, 15852-15869; e) K. D. Benkstein, J. T. Hupp, C. L. Stern, Angew. Chem. 2000, 112, 3013-3015; Angew. Chem. Int. Ed. 2000, 39, 2891-2893; f) P. H. Dinolfo, M. E. Williams, C. L. Stern, J. T. Hupp, J. Am. Chem. Soc. 2004, 126, 12989-13001; g) M. Fujita, M. Aoyagi, F. Ibukuro, K. Ogura, K. Yamaguchi, J. Am. Chem. Soc. 1998, 120, 611-612; h) A. Company, L. Gómez, J. M. López Valbuena, R. Mas-Ballesté, J. Benet-Buchholz, A. Llobet, M. Costas, Inorg. Chem. 2006, 45, 2501-2508; i) C. Addicott, I. Oesterling, T. Yamamoto, K. Müllen, P. J. Stang, J. Org. Chem. 2005, 70, 797-801; j) N. Das, P. S. Mukherjee, A. M. Arif, P. J. Stang, J. Am. Chem. Soc. 2003, 125, 13950-13951.

[9] a) T. Sawada, M. Yoshizawa, S. Sato, M. Fujita, Nat. Chem. 2009, 1, 53-56; b) Y. R. Zheng, H. B. Yang, K. Ghosh, L. Zhao, P. J. Stang, Chem. Eur. J. 2009, 15, 7203-7214.

[10] C. Peinador, E. Pia, V. Blanco, M. D. Garcia, J. M. Quintela, Org. Lett. 2010, 12, 1380-1383.

[11] Th. Zincke, Justus Liebigs Ann. Chem. 1903, 330, 361-374.

[12] a) V. Blanco, D. Abella, E. Pia, C. Platas-Iglesias, C. Peinador, J. M. Quintela, Inorg. Chem. 2009, 48, 4098-4107; b) V. Blanco, A. Gutierrez, C. Platas-Iglesias, C. Peinador, J. M. Quintela, J. Org. Chem. 2009, 74, 6577-6583; c) V. Blanco, M. Chas, D. Abella, E. Pia, C.
Platas-Iglesias, C. Peinador, J. M. Quintela, Org. Lett. 2008, 10, 409412; d) V. Blanco, M. Chas, D. Abella, C. Peinador, J. M. Quintela, J. Am. Chem. Soc. 2007, 129, 13978-13986; e) M. Chas, D. Abella V. Blanco, E. Pia, G. Blanco, A. Fernandez, C. Platas-Iglesias, C. Peinador, J. M. Quintela, Chem. Eur. J. 2007, 13, 8572-8582.

[13] a) M. Fujita, F. Ibukuro, K. Yamaguchi, K. Ogura, J. Am. Chem. Soc. 1995, 117, 4175-4176; b) C. J. Kuehl, S. D. Huang, P. J. Stang, J. Am. Chem. Soc. 2001, 123, 9634-9641.

[14] F. Diederich, K. Dick, J. Am. Chem. Soc. 1984, 106, 8024-8036.

[15] W. W. Davis, M. E. Krahl, G. H. A. Clowes, J. Am. Chem. Soc. 1942 64, 108-110.

[16] D. Mackay, W. Y. Shiu, J. Chem. Eng. Data 1977, 22, 399-402.

[17] J.-M. Lehn, J. Blacker, J. Jazwinski, Eur. Pat. Appl. EP 244320A1 19871104, 1987.

[18] W. J. Scot, A. Redman, J. Johnson, J. E. Wood, H. Paulsen, U. Khire, J. Dumas, R. A. Smith, W. Lee, H. Hatoum-Mokdad, B. Riedl, T. B. Lowinger, Aust. Pat. Appl. 2006201959, 2006.

[19] a) P. R. Ashton, S. E. Boyd, A. Brindle, S. J. Langford, L. PérezGarcía, J. A. Preece, F. M. Raymo, N. Spencer, J. F. Stoddart, A. J. P White, D. J. Williams, New J. Chem. 1999, 23, 587-602; b) J. A. Blake, G. Baum, N. R. Champness, S. S. M. Chung, P. A. Cooke, D Fenske, A. N. Khlobystov, D. A. Lemenovskii, W.-S. Li, M. Schröder, J. Chem. Soc. Dalton Trans. 2000, 4285-4291.

[20] L. G. Longsworth, J. Phys. Chem. 1960, 64, 1914-1917.

[21] T. Megyes, H. Jude, T. Grósz, I. Bakó, R. Radnai, G. Tárkányi, G. Pálinkás, P. J. Stang, J. Am. Chem. Soc. 2005, 127, 10731-10738.

[22] Gaussian 09, Revision A.02, M. J. Frisch, G. W. Trucks, H. B. Schlegel, G. E. Scuseria, M. A. Robb, J. R. Cheeseman, G. Scalmani, V. Barone, B. Mennucci, G. A. Petersson, H. Nakatsuji, M. Caricato, X. Li, H. P. Hratchian, A. F. Izmaylov, J. Bloino, G. Zheng, J. L. Sonnenberg, M. Hada, M. Ehara, K. Toyota, R. Fukuda, J. Hasegawa, M. Ishida, T. Nakajima, Y. Honda, O. Kitao, H. Nakai, T. Vreven, J. A. Montgomery, Jr., J. E. Peralta, F. Ogliaro, M. Bearpark, J. J. Heyd, E. Brothers, K. N. Kudin, V. N. Staroverov, R. Kobayashi, J. Normand, K. Raghavachari, A. Rendell, J. C. Burant, S. S. Iyengar, J. Tomasi, M. Cossi, N. Rega, J. M. Millam, M. Klene, J. E. Knox, J. B. Cross, V. Bakken, C. Adamo, J. Jaramillo, R. Gomperts, R. E. Stratmann, O. Yazyev, A. J. Austin, R. Cammi, C. Pomelli, J. W. Ochterski, R. L. Martin, K. Morokuma, V. G. Zakrzewski, G. A. Voth, P. Salvador, J. J. Dannenberg, S. Dapprich, A. D. Daniels, O. Farkas, J. B. Foresman, J. V. Ortiz, J. Cioslowski, D. J. Fox, Gaussian, Inc., Wallingford CT, 2009.

[23] A. D. Becke, J. Chem. Phys. 1993, 98, 5648-5652.

[24] C. Lee, W. Yang, R. G. Parr, Phys. Rev. B 1988, 37, 785-789.

[25] GaussView, Version 2; Gaussian, Inc.: Pittsburgh, PA, 1998

[26] P. J. Hay, W. R. Wadt, J. Chem. Phys. 1985, 82, 270-283.

[27] SHELX-97, An Integrated System for Solving and Refining Crystal Structures from Diffraction Data, G. M. Sheldrick, University of Göttingen (Germany), 1997. 